\title{
KAJIAN PENENTUAN SEMPADAN SUNGAI PERKOTAAN KABUPATEN BOJONEGORO
}

\author{
Widiyanto Hari Subagyo Widodo1 ${ }^{1)}$, Annisaa Hamidah Imaduddina ${ }^{2)}$ Ibnu Sasongko $^{\text {3) }}$ \\ Institut Teknologi Nasional Malang \\ 1harry_4444@ rocketmail.com, ${ }^{2}$ nisa_pwk@yahoo.com, ${ }^{3 \text { ibnukoko59@gmail.com }}$
}

\begin{abstract}
Abstrak
(DAS) Daerah Aliran Sungai merupakan bagian bumi yang mengandung air dan kekayaan alam yang harus dilindungi, dikuasai, diatur dan dikelola negara dalam rangka mewujudkan kemakmuran masyarakyat. Tujuan penelitian ini adalah penentuan deliniasi kawasan yang menjadi lokus amatan dan penyajian hasil penentuan sempadan sungai di wilayah Kecamatan Bojonegoro dan Kecamatan Kapas. Analisis yang dilakukan terkait dengan penentuan sempadan sungai salah satunya menggunakan interpretasi dari hasil profile graph dengan menggunakan data DEM dimana hasilnya sempadan sungai yang ada dikedua kecamatan berbentu $U$ yang paling mendominasi dibanding $V$. Berdasarkan hasil analisis tipologi sungai maka tingkat Risiko bencana banjir Rendah (C2) hingga Sedang (C3).
\end{abstract}

Kata kunci: Kajian,sempadan sungai, bojonegoro

(DAS) Watershed is the part of the earth that contains water and natural resources that must be protected, controlled, regulated, and managed by the state in order to realize the prosperity of the people. The purpose of this study was to determine the delineation of the area as the locus of observation and to present the results of determining river boundaries in the Districts of Bojonegoro and Kapas. The analysis carried out is related to the determination of river boundaries, one of which uses the interpretation of the results of profile graphs using DEM data where the results are river borders in two $U$-shaped districts that dominate compared to $V$. Based on the results of river typology analysis, the level of flood risk is low (C2) to Medium (C3).

Keywords: Study, river border, bojonegoro

\section{PENDAhUluan}

Daerah Aliran Sungai (DAS) adalah suatu kesatuan ekosistem yang terdiri atas sumber daya alam tanah, air dan vegetasi serta sumber daya manusia sebagai pemanfaat sumber daya alam. Daerah Aliran Sungai dibeberapa wilayah dikaitkan dengan kepadatan penduduknya dan pemanfaatan sumber daya alamnya yang intensif, sehingga terdapat indikasi belakangan ini bahwa kondisi DAS semakin menurun dengan indikasi meningkatnya kejadian tanah longsor, erosi, sedimentasi, dan banjir. Di sisi lain tuntutannya tinggi terhadap kemampuan sebagai menunjang sistem kehidupan, baik masyarakat dibagian hulu maupun hilir. DAS adalah kesatuan alam yang koheren yang melintasi batas-batas administrative. Di dalam daerah aliran sungai, masyarakat dan ekologi, daratan dan air dan hulu hilir yang saling mempengaruhi. dalam pengelolaannya terkait ini secara efektif, dan melalui pendekatan multi sektoral (Powell, 1890 dalam Mostert 2017).

Secara garis besar, terdapat tiga bagian sistem DAS yaitu bagian hulu, tengah, dan hilir. Ekosistem DAS hulu sangat penting pada sistem DAS karena berfungsi sebagai perlindungan sistem tata air DAS secara keseluruhan (Putra,2019). DAS juga 
merupakan suatu unit hidrologi dasar lanskap yang mencakup "sistem cascading" dari "hillslope dan subsistem saluran" yang terhubung (Blodget,2021). Area cekungan DAS terbagi menjadi beberapa subbasin, yang kemudian dibagi lagi menjadi Hidrologi. Unit Respon yang terdiri dari homogen penggunaan lahan, manajemen dan karakteristik tanah Čerkasova,2016).

Berdasarkan SK Menteri Kehutanan Nomor SK. 328/Menhut-II/2009 tanggal 12 Juni 2009 tentang Penetapan Daerah Aliran Sungai (DAS) Prioritas Dalam Rangka Rencana Pembangunan Jangka Menengah (RPJM) 2010-2014 telah ditetapkan sebanyak 108 DAS di Indonesia dalam kondisi kritis dan menjadi prioritas untuk penanganan dan pemulihanan DAS (Fatahilah,2013). Peraturan Menteri Pekerjaan Umum No 63.PRT/1992 tentang Garis Sempadan Sungai, Daerah Manfaat Sungai, Daerah Penguasaan Sungai dan bekas Sungai; serta Peraturan Pemerintah Nomor 38 Tahun 2011 Tentang Sungai diatur dalam Pemanfaatan ruang di daerah sempadan sungai Keppres Nomor 32 Tahun 1990 tentang Pengelolaan Kawasan Lindung. Di dalam peraturan perundangan disebutkan bahwa daerah sempadan sungai dilarang digunakan untuk bangunan gedung (Suprapti dkk, 2014).

Pengelolaan DAS yang dilakukan secara terpadu diperlukan dengan melibatkan pemangku kepentingan pengelolaan sumberdaya alam yang terdiri dari unsurunsur masyarakat, dunia usaha, pemerintah, serta pemerintah daerah dengan prinsip keterpaduan, kesetaraan, dan berkomitmen untuk menerapkan penyelenggaraan pengelolaan sumberdaya alam yang adil, efektif, efisien, dan berkelanjutan dalam penyelenggaraan pengelolaan DAS terpadu tersebut (Ariyani,2020).

Salah satu dari permasalahan penggunaan lahan saat ini adaalh alih fungsi lahan. Alih fungsi lahan adalah perubahan fungsi lahan sebagian atau seluruh kawasan lahan dari fungsinya semula (seperti yang direncanakan) menjadi fungsi lain yang menjadi dampak negatif (bermasalah) terhadap lingkungan dan potensi lahan. Alih fungsi lahan disebabkan oleh keperluan dalam memenuhi kebutuhan penduduk yang makin meningkatnya tuntutan akan mutu kehidupan yang lebih baik (Utomo et al., 1992 dalam Widya, 2014). Penyebab utama permasalahan DAS dapat dikelompokkan menjadi dua yakni: 1) faktor alam seperti curah hujan, kelerengan dan jenis tanah dan 2) faktor manusia, seperti faktor kebijakan dan sosial ekonomi (Departemen Pekerjaan Umum, 2004 dalam Widiyanto, 2018).

Sebagai sistem pembawa aliran dari DAS sungai perlu ruang layak dalam menjalankan fungsinya baik mengalirkan debit banjir maupun saat mengalirkan debit aliran rendah. Seiring wilayah yang berkembang serta batas antara sungai sebagai suatu sistem pembawa aliran, wilayah permukiman serta pemanfaatan lahan yang lain semakin bergeser ke arah sungai dan tentu saja fungsi sungai terganggu sebagai pembawa aliran dan juga mengurangi nilai pemanfaatan lahan yang ada mengingat akan sering tergenang di saat kondisi banjir. Burby dan French (1981) dalam Gay tahun 2018, menyatakan bahwa untuk pembatasan pembangunan di daerahdaerah yang rawan dan memiliki tingkat risiko tinggi terhadap bahaya yang terkait dengan alam, salah satunya banjir diperlukan salah satu peran perencanaan pola dan struktur tata ruang.

Kabupaten Bojonegoro merupakan kawasan yang dilalui oleh Sungai Bengawan Solo dari beberapa kabupaten/kota lainnya yang setiap tahunnya berisiko terhadap bencana banjir. Pemanfaatan lahan disekitar DAS tentu menjadi pengawasan khusus dalam mengurangi risiko bencana tersebut. Berdasarkan hal tersebut, maka perlu adanya kajian penentuan sempadan sungai di Kabupaten Bojonegoro, sehingga kawasan sempadan sungai tersebut dapat berfungsi optimal dalam keberlangsungan penjagaan sungai dalam tugas sungai sebagai pembawa aliran untuk suatu sistem DAS dalam memberi manfaat yang besar bagi masyarakat sekaligus menjaga kelestarian sungai dan juga pengurangan terhadap bahaya banjir serta bencana yang sering terjadi akibat adanya penyalahgunaan daerah bantaran sungai yang tidak terkontrol. Oleh Karena itu tujuan penelitian ini adalah penentuan deliniasi kawasan yang menjadi lokus amatan dan penyajian hasil penentuan sempadan sungai di 
wilayah Kecamatan Bojonegoro dan Kecamatan Kapas.

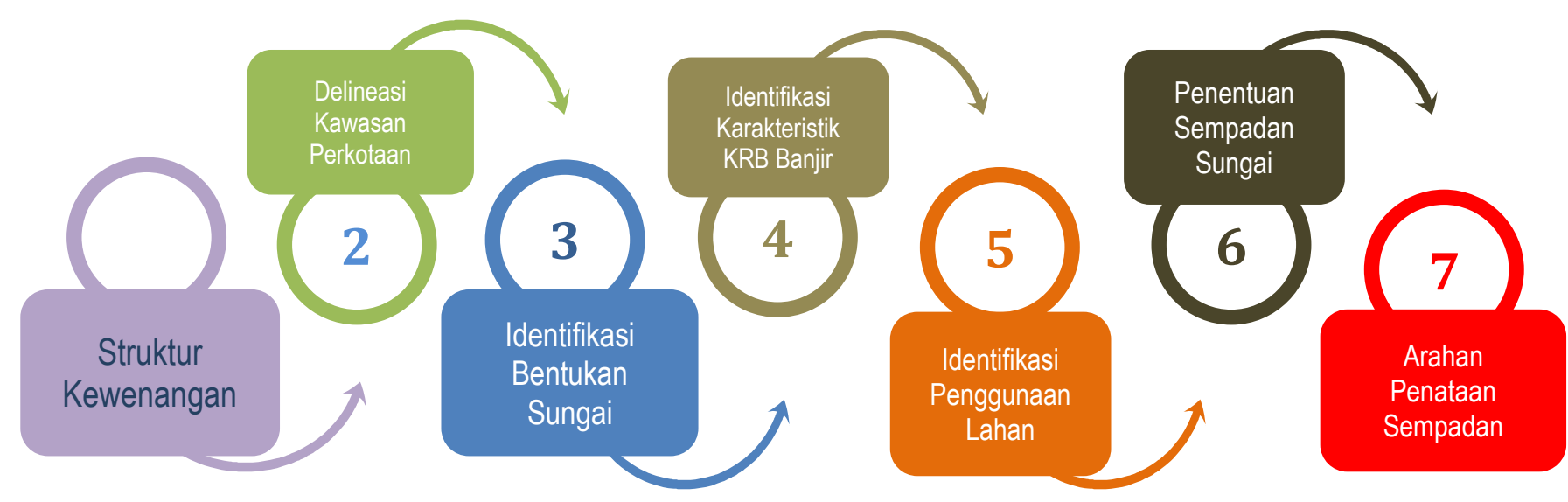

Gambar 1. Kerangka Kerja/Literatur

\section{METODE PENELITIAN}

Metode pengumpulan data terdiri dari survei primer dan survei sekunder. Survei Primer adalah survei yang dilakukan di lapangan pada kawasan untuk mencari datadata dan gambaran potensi permasalahan di lapangan. Sedangkan survei sekunder berupa survei untuk mendapatkan data-data berupa citra satelit dan dokumen yang berkaitan dengan Kajian penentuan garis sempadan sungai di wilayah perkotaan Kabupaten Bojonegoro yang telah disusun oleh instansiinstansi maupun oleh perseorangan.

Output yang diperoleh:

1) Rencana kerja dan metodologi yang telah disepakati;

2) Data dan informasi terkait lokasi kawasan sempadan sungai di perkotan Kabupaten Bojonegoro

3) Peta Dasar skala $1: 50.000$ untuk wilayah administrasi Kabupaten Bojonegoro ;

4) Peta skala $1: 5.000$ untuk kawasan sempadan

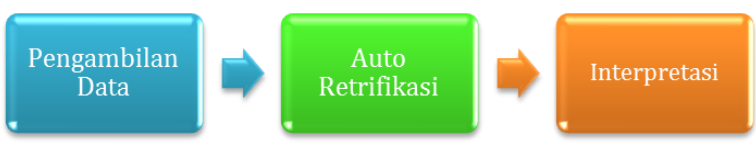

Gambar 2. Pengolahan Citra Resolusi Tinggi

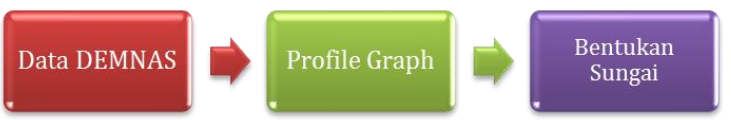

Gambar 3. Pengolahan Data DEM

Proses analisa menggunakan analisis kualitatif dengan melakukan analisis tipologi atau pengelompokan, dan perbandingan antara data serta peraturan/kebijakan. Pada tahapan analisa ini terdiri dari 6 kegiatan, yaitu :

1) Identifikasi Bentukan Sungai, Identifikasi bentukan palung sungai $U$ dan $\mathrm{V}$ dapat diketahui dengan menggunakan analisis transek. Metode transek dapat dibedakan menjadi 2 yaitu transek garis (Line Transect) dan transek jalur (Strip Transect)

2) Identifikasi Karakteristik Kawasan Risiko Banjir, dengan cara menghitung debit sungai, identifikasi pelebaran bantaran sungai. 
3) Identifikasi Penggunaan Lahan di Sekitar Sempadan Sungai, klasifikasi kawasan budidaya dan lindung serta jumlah bangunan yang terdapat dalam sempadan sungai dan jenis bangunan yang terdapat dalam sempadan sungai.

4) Menganalisis Tipologi Sungai berdasarkan Karakteristik Sungai, KRB Banjir dan Penggunaan Lahan Kawasan Sempadan Sungai, mengelompokan dan mendelineasi kawasan sempadan sungai menjadi beberapa segmen berdasarkan hasil identifikasi karakteristik sungai yang terdiri dari sungai bertanggul dan tidak bertanggul, sungai berbentuk $\mathrm{U}$ dan $\mathrm{V}$, serta sungai bermeander dan nonmeander, dan mengelompokan kawasan sempadan sungai didasarkan juga pada identifikasi kawasan risiko bencana banjir dengan tingkat risiko rendah, menengah dan tinggi.

5) Menentukan Daerah Sempadan Sungai, penentuan sempadan sungai di wilayah Perkotaan di Kabupaten Bojonegoro dengan mengacu pada Peraturan Menteri Pekerjaan Umum Dan Perumahan Rakyat No 28/PRT/M/2015 Tentang Penetapan Garis Sempadan Sungai dan Garis Sempadan Danau.

6) Merumuskan Arahan Penataan Ruang di Daerah Sempadan Sungai, dilakukannya pengendalian pemanfaatan ruang di daerah sempadan sungai berdasarkan identifikasi jenis penggunaan lahan termasuk kawasan budidaya atau kawasan lindung.

\section{HASIL DAN PEMBAHASAN}

\section{A. Identifikasi Bentukan Sungai Wilayah kajian Kabupaten Bojonegoro}

Identifikasi bentukan sungai pada Kecamatan Bojonegoro terbagi menjadi 21 segmentasi sungai. Identifikasi dilakukan dengan analisis transek segmentasi sungai. Output dari analisis tersebut adalah profile graph yang mempermudah dalam menentukan bentukan sungai. Identifikasi dilakukan untuk mengetahui bentukan palung sungai $\mathrm{U}$ atau palung sungai $\mathrm{V}$ pada penampang sungai. Dalam mendetailkan identifikasi tersebut, dilakukan dengan membagi beberapa segmentasi sungai pada
Kecamatan Bojonegoro dan Kecamatan Kapas.

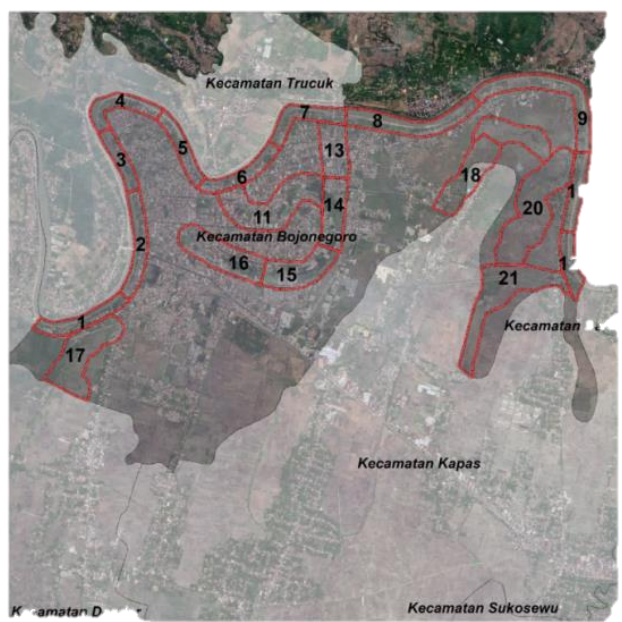

Sumber: Hasil Analisa Widiyanto, 2017

Gambar 4. Peta Deliniasi Pembagian Segmentasi Sungai Kecamatan Bojongoro

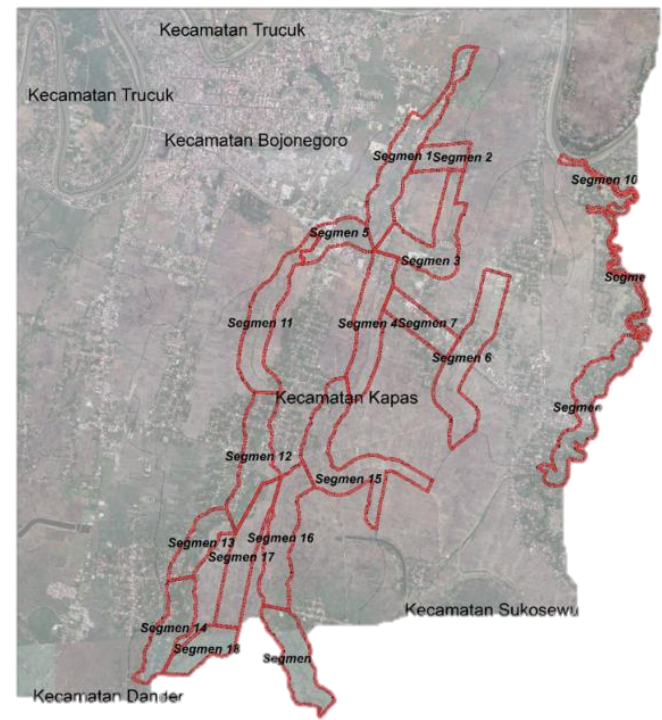

Sumber: Hasil Analisa Widiyanto, 2017

Gambar 5. Peta Deliniasi Pembagian Segmentasi Sungai Kecamatan Kapas

Adapun dengan teridentifikasinya bentukan palung sungai, maka dapat juga terlihat karakteristik risiko bencana pada segmentasi sungai tersebut. Hal ini dikarenakan palung sungai $\mathrm{U}$ memiliki risiko bencana banjir, sedangkan palung sungai $\mathrm{V}$ memiliki risiko banjir yang rendah. Berikut adalah uraian dari hasil identifikasi tersebut. 
Adapun hasil analisis dari segmentasi tersebut disajikan pada penjelasan berikut ini.

Tabel 1. Bentukan Sungai Wilayah Kajian Kabupaten Bojonegoro

\begin{tabular}{|c|c|c|c|}
\hline Segmen & $\begin{array}{c}\text { Hasil Permodelan Debit } \\
\text { Banjir Q }\end{array}$ & $\begin{array}{c}\text { Terjadinya } \\
\text { Banjir Dari Tepi } \\
\text { Palung (Meter) } \\
\end{array}$ & Bentukan Sungai \\
\hline \multicolumn{4}{|c|}{ KECAMATAN BOJONEGORO } \\
\hline Segmen 1 & 20 & 96 & $\mathrm{U}$ \\
\hline Segmen 2 & 20 & 100 & $\mathrm{U}$ \\
\hline Segmen 3 & 20 & 100 & $\mathrm{U}$ \\
\hline Segmen 4 & 20 & 103 & $\mathrm{U}$ \\
\hline Segmen 5 & 20 & 115 & $\mathrm{U}$ \\
\hline Segmen 6 & 20 & 60 & $\mathrm{U}$ \\
\hline Segmen 7 & 20 & 86 & $\mathrm{U}$ \\
\hline Segmen 8 & 20 & 60 & $\mathrm{U}$ \\
\hline Segmen 9 & 20 & 143 & $\mathrm{U}$ \\
\hline Segmen 10 & 20 & 70 & $\mathrm{U}$ \\
\hline Segmen 11 & 20 & 88 & $\mathrm{U}$ \\
\hline Segmen 12 & - & - & $\mathrm{V}$ \\
\hline Segmen 13 & - & - & $\mathrm{V}$ \\
\hline Segmen 14 & - & - & $\mathrm{V}$ \\
\hline Segmen 15 & - & - & $\mathrm{U}$ \\
\hline Segmen 16 & - & - & $\mathrm{V}$ \\
\hline Segmen 17 & - & - & $\mathrm{V}$ \\
\hline Segmen 18 & - & - & $\mathrm{V}$ \\
\hline Segmen 19 & - & - & $\mathrm{V}$ \\
\hline Segmen 20 & - & - & $\mathrm{V}$ \\
\hline Segmen 21 & - & - & $\mathrm{V}$ \\
\hline \multicolumn{4}{|c|}{ KECAMATAN KIPAS } \\
\hline Segmen 1 & - & - & $\mathrm{V}$ \\
\hline Segmen 2 & - & - & $\mathrm{V}$ \\
\hline Segmen 3 & - & - & $\mathrm{V}$ \\
\hline Segmen 4 & - & - & $\mathrm{V}$ \\
\hline Segmen 5 & - & - & $\mathrm{V}$ \\
\hline Segmen 6 & - & - & $\mathrm{U}$ \\
\hline Segmen 7 & - & - & $\mathrm{U}$ \\
\hline Segmen 8 & - & - & $\mathrm{V}$ \\
\hline Segmen 9 & - & - & $\mathrm{V}$ \\
\hline Segmen 10 & - & - & $\mathrm{U}$ \\
\hline Segmen 11 & - & - & $\mathrm{U}$ \\
\hline Segmen 12 & - & - & $\mathrm{U}$ \\
\hline Segmen 13 & - & - & $\mathrm{U}$ \\
\hline Segmen 14 & - & - & $\mathrm{U}$ \\
\hline Segmen 15 & - & - & $\mathrm{V}$ \\
\hline Segmen 16 & - & - & $\mathrm{V}$ \\
\hline Segmen 17 & - & - & $\mathrm{V}$ \\
\hline Segmen 18 & - & - & $\mathrm{V}$ \\
\hline Segmen 19 & - & - & $\mathrm{V}$ \\
\hline
\end{tabular}

Sumber: Hasil Analisa Widiyanto, 2017 
Dari hasil profile graph dan analisis transek pada Kecamatan Bojonegoro dan Kecamatan Kipas maka dapat tarik kesimpulan bahwa sungai yang memiliki bentukan U Karena memiliki palung sungai yang landai, hal ini dapat diartikan pada dataran banjir ini memiliki risiko banjir yang tinggi apabila berada pada kawasan rawan bencana banjir. Dengan sungai bermeander, risiko banjir pada tepi palung sungai akan berpotensi lebih besar karena memiliki topografi bergelombang dan wilayah yang berpotensi banjir akan dapat melebihi terjadinya banjir dari tepi palung (meter). Sedangkan bentukan sungai U dan V karena memiliki palung sungai yang curam dengan sungai tidak bermeander. Karena memiliki palung sungai yang curam dan topografi pada tepi palung tinggi, hal ini dapat diartikan pada segmen ini tidak terkena bencana alam atau Risiko banjir yang rendah.

\section{B. Analisis Tipologi Sungai Wilayah kajian Kabupaten Bojonegoro}

Pada analisis ini akan dilakukannya pengelompokkan dan delineasi kawasan sempadan sungai menjadi beberapa segmen berdasarkan hasil identifikasi karakteristik sungai yang terdiri dari sungai bertanggul dan tidak bertanggul, sungai berbentuk $\mathrm{U}$ dan $\mathrm{V}$, serta sungai bermeander dan non-meander. Selain itu, dikelompokkan kawasan sempadan sungai berdasarkan pada identifikasi kawasan risiko bencana banjir dengan tingkat risiko rendah, menengah dan tinggi serta jenis penggunaan lahannya. Tipologi sungai ini dibedakan menjadi Wilayah kajian Kecamatan Bojonegoro dan Kecamatan Kapas, dimana dalam kedua kecamatan tersebut terdapat kawasan perkotaan dan perdesaan.

\section{Analisis Tipologi Sungai Wilayah kajian Kecamatan Bojonegoro}

Segmen 1 berada pada sungai Bengawan Solo dan merupakan wilayah perkotaan dan berdasarkan hasil analisis transek memiliki bentukan sungai $\mathrm{U}$ bermeander, tidak bertanggul serta berada pada tingkat rawan bencana banjir $\mathrm{C} 1$ (tinggi) dengan jenis penggunaan lahan di sempadan sungai nya adalah perumahan, kebun campur, sawah, pendidikan, perdagangan dan jasa, peribadatan, kesehatan, tegalan dan perkantoran. Diantara penggunaan lahan tersebut, pada segmen 1 didominasi oleh perumahan dengan luas 7,77 ha dan merupakan kawasan budidaya. Berikut merupakan peta segmen 1 .

Segmen 2 berada pada sungai Bengawan Solo dan merupakan wilayah perkotaan dan berdasarkan hasil analisis transek memiliki bentukan sungai $U$ bermeander, tidak bertanggul serta berada pada tingkat rawan bencana banjir C2 (sedang) dengan jenis penggunaan lahan di sempadan sungai nya adalah perumahan, kebun campur, pendidikan, perdagangan dan jasa, kesehatan, peribadatan, pertahanan dan keamanan, perkantoran, pariwisata dan hiburan, olahraga dan RTH. Diantara penggunaan lahan tersebut, pada segmen 2 didominasi oleh perumahan dengan luas 10,89 ha dan merupakan kawasan budidaya.

Segmen 3 berada pada sungai Bengawan Solo dan merupakan wilayah perkotaan. Berdasarkan hasil analisis transek memiliki bentukan sungai $U$ tidak bermeander, tidak bertanggul serta berada pada tingkat rawan bencana banjir $\mathrm{C} 2$ (sedang) dengan jenis penggunaan lahan di sempadan sungai nya adalah perumahan, kebun campur, peribadatan dan perkantoran. Diantara penggunaan lahan tersebut, pada segmen 3 didominasi oleh kebun campur dengan luas 6,13 ha dan merupakan kawasan budidaya.

Segmen 4 berada pada sungai Bengawan Solo dan merupakan wilayah perkotaan. Berdasarkan hasil analisis transek memiliki bentukan sungai $U$ bermeander, tidak bertanggul serta berada pada tingkat rawan bencana banjir C2 (sedang) dengan jenis penggunaan lahan di sempadan sungai nya adalah perumahan, kebun campur, pendidikan, perdagangan dan jasa, peribadatan, tegalan dan jalan. Diantara penggunaan lahan tersebut, pada segmen 4 didominasi oleh kebun campur dengan luas 11,56 ha dan merupakan kawasan budidaya.

Segmen 5 berada pada sungai Bengawan Solo dan merupakan wilayah perkotaan. Berdasarkan hasil analisis transek 
memiliki bentukan sungai $U$ bermeander, tidak bertanggul serta berada pada tingkat rawan bencana banjir C3 (rendah) dengan jenis penggunaan lahan di sempadan sungai nya adalah perumahan, kebun campur, sawah, pendidikan, perdagangan dan jasa, peribadatan, tegalan dan perkantoran. Diantara penggunaan lahan tersebut, pada segmen 5 didominasi oleh kebun campur dengan luas 8,79 ha dan merupakan kawasan budidaya.

Segmen 6 berada pada sungai Bengawan Solo dan merupakan wilayah perkotaan. Berdasarkan hasil analisis transek memiliki bentukan sungai $U$ bermeander, tidak bertanggul serta berada pada tingkat rawan bencana banjir C3 (rendah) dengan jenis penggunaan lahan di sempadan sungai nya adalah perumahan, kebun campur, kesehatan, pendidikan, perdagangan dan jasa, industri, peribadatan, pertahanan dan keamanan serta pariwisata dan hiburan. Diantara penggunaan lahan tersebut, pada segmen 6 didominasi oleh perumahan dengan luas 8,18 ha dan merupakan kawasan budidaya.

Segmen 7 berada pada sungai Bengawan Solo dan merupakan wilayah perkotaan. Berdasarkan hasil analisis transek memiliki bentukan sungai $U$ bermeander, tidak bertanggul serta berada pada tingkat rawan bencana banjir C2 (sedang) dengan jenis penggunaan lahan di sempadan sungai nya adalah perumahan, kebun campur, sawah irigasi., peribadatan, pariwisata dan hiburan dan tegalan. Diantara penggunaan lahan tersebut, pada segmen 7 didominasi oleh kebun campur dengan luas 9,83 ha dan merupakan kawasan budidaya.

Segmen 8 berada pada sungai Bengawan Solo dan merupakan wilayah perkotaan. Berdasarkan hasil analisis transek memiliki bentukan sungai $U$ bermeander, tidak bertanggul serta berada pada tingkat rawan bencana banjir C2 (sedang) dengan jenis penggunaan lahan di sempadan sungai nya adalah perumahan, kebun campur, pendidikan, perdagangan dan jasa, kesehatan, peribadatan, pariwisata dan hiburan serta perkantoran. Diantara penggunaan lahan tersebut, pada segmen 8 didominasi oleh kebun campur dengan luas 20,37 ha dan merupakan kawasan budidaya.

Segmen 9 berada pada sungai Bengawan Solo dan merupakan wilayah perkotaan. Berdasarkan hasil analisis transek memiliki bentukan sungai $U$ bermeander, tidak bertanggul serta berada pada tingkat rawan bencana banjir C2 (sedang) dengan jenis penggunaan lahan di sempadan sungai nya adalah perumahan, kebun campur, sawah, pendidikan, perdagangan dan jasa, industri, peribadatan dan tegalan. Diantara penggunaan lahan tersebut, pada segmen 9 didominasi oleh kebun campur dengan luas 15,37 ha dan merupakan kawasan budidaya.

Segmen 10 berada pada sungai Bengawan Solo dan merupakan wilayah perkotaan. Berdasarkan hasil analisis transek memiliki bentukan sungai $U$ tidak bermeander, tidak bertanggul serta berada pada tingkat rawan bencana banjir $\mathrm{C} 2$ (sedang) dengan jenis penggunaan lahan di sempadan sungai nya adalah perumahan, kebun campur dan sawah. Diantara penggunaan lahan tersebut, pada segmen 10 didominasi oleh kebun campur dengan luas 13,62 ha dan merupakan kawasan budidaya.

Segmen 11 berada pada sungai Bengawan Solo dan merupakan wilayah perkotaan. Berdasarkan hasil analisis transek memiliki bentukan sungai $U$ bermeander, tidak bertanggul serta berada pada tingkat rawan bencana banjir C3 (rendah) dengan jenis penggunaan lahan di sempadan sungai nya adalah perumahan, kebun campur, sawah, pendidikan, perdagangan dann jasa, industri, peribadatan, tegalan, perkantoran, kesehatan serta pariwisata dan hiburan. Diantara penggunaan lahan tersebut, pada segmen 11 didominasi oleh perumahan dengan luas 45,74 ha dan merupakan kawasan budidaya.

Segmen 12 berada pada sungai Bengawan Solo dan merupakan wilayah perkotaan. Berdasarkan hasil analisis transek memiliki bentukan sungai $\mathrm{V}$ tidak bermeander, tidak bertanggul serta berada pada tingkat rawan bencana banjir C3 (rendah) dengan jenis penggunaan lahan di sempadan sungai nya adalah perumahan, kebun campur, sawah, pendidikan, perdagangan dan jasa, industri, peribadatan, tegalan, perkantoran, pertahanan dan 
keamanan, kesehatan serta pariwisata dan hiburan. Diantara penggunaan lahan tersebut, pada segmen 12 didominasi oleh perumahan dengan luas 33,37 ha dan merupakan kawasan budidaya.

Segmen 13 merupakan wilayah perkotaan dan berdasarkan hasil analisis transek memiliki bentukan sungai $\mathrm{V}$ tidak bermeander, bertanggul serta berada pada tingkat rawan bencana banjir C3 (rendah) dengan jenis penggunaan lahan di sempadan sungai nya adalah perumahan, kebun campur, sawah, pendidikan, perdagangan dan jasa, industri, peribadatan, tegalan, perkantoran dan kesehatan. Diantara penggunaan lahan tersebut, pada segmen 13 didominasi oleh perumahan dengan luas 18,55 ha dan merupakan kawasan budidaya.

Segmen 14 merupakan wilayah perkotaan dan berdasarkan hasil analisis transek memiliki dua bentukan yaitu sungai U. Segmen sungai tersebut tidak bermeander, bertanggul serta berada pada tingkat rawan bencana banjir C3 (rendah) dengan jenis penggunaan lahan di sempadan sungai nya adalah perumahan, kebun campur, sawah, pendidikan, perdagangan dan jasa, kesehatan, peribadatan, tegalan, perkantoran serta pariwisata dan hiburan. Diantara penggunaan lahan tersebut, pada segmen 14 didominasi oleh perumahan dengan luas 17,79 ha dan merupakan kawasan budidaya.

Segmen 15 merupakan wilayah perkotaan dan berdasarkan hasil analisis transek memiliki bentukan sungai $U$ bermeander, bertanggul serta berada pada tingkat rawan bencana banjir C3 (rendah) dengan jenis penggunaan lahan di sempadan sungai nya adalah perumahan, kebun campur, sawah, pendidikan, perdagangan dan jasa, kesehatan, peribadatan, pariwisata dan hiburan, tegalan dan perkantoran. Diantara penggunaan lahan tersebut, pada segmen 15 didominasi oleh perumahan dengan luas 19,03 ha dan merupakan kawasan budidaya.

Segmen 16 merupakan wilayah perkotaan dan berdasarkan hasil analisis transek memiliki bentukan sungai $\mathrm{V}$ bermeander, bertanggul serta berada pada tingkat rawan bencana banjir C3 (rendah) dengan jenis penggunaan lahan di sempadan sungai nya adalah perumahan, kebun campur, sawah, pendidikan, perdagangan dan jasa, kesehatan, peribadatan, tegalan, pariwisata dan hiburan. Diantara penggunaan lahan tersebut, pada segmen 16 didominasi oleh perumahan dengan luas 18,52 ha dan merupakan kawasan budidaya.

Segmen 17 merupakan wilayah perkotaan dan berdasarkan hasil analisis transek memiliki bentukan sungai $\mathrm{V}$ tidak bermeander, bertanggul serta berada pada tingkat rawan bencana banjir $\mathrm{C} 1$ (tinggi) dengan jenis penggunaan lahan di sempadan sungai nya adalah perumahan, kebun campur, pariwisata dan hiburan, pendidikan, perdagangan dan jasa, industri, peribadatan, kesehatan, tegalan, perkantoran, pertahanan dan keamanan. Diantara penggunaan lahan tersebut, pada segmen 17 didominasi oleh perumahan dengan luas 29,42 ha dan merupakan kawasan budidaya.

Segmen 18 merupakan wilayah perkotaan dan berdasarkan hasil analisis transek memiliki bentukan sungai V bermeander, tidak bertanggul serta berada pada tingkat rawan bencana banjir C3 (rendah) dengan jenis penggunaan lahan di sempadan sungai nya adalah perumahan, kebun campur, sawah, pendidikan, perdagangan dan jasa, pertahanan dan keamanan, peribadatan, tegalan dan kesehatan. Diantara penggunaan lahan tersebut, pada segmen 18 didominasi oleh sawah dengan luas 32,58 ha dan merupakan kawasan budidaya.

Segmen 19 merupakan wilayah perkotaan dan berdasarkan hasil analisis transek memiliki dua bentukan sungai yaitu bentuk U. Segmen sungai tersebut bermeander, tidak bertanggul serta berada pada tingkat rawan bencana banjir C3 (rendah) dengan jenis penggunaan lahan di sempadan sungai nya adalah perumahan, kebun campur, sawah, perdagangan dan jasa dan industri. Diantara penggunaan lahan tersebut, pada segmen 19 didominasi oleh sawah dengan luas 41,62 ha dan merupakan kawasan budidaya.

Segmen 20 merupakan wilayah perkotaan dan berdasarkan hasil analisis transek memiliki bentukan sungai $U$ bermeander, tidak bertanggul serta berada pada tingkat rawan bencana banjir C3 
(rendah) dengan jenis penggunaan lahan di sempadan sungai nya adalah perumahan, kebun campur, sawah, perdagangan dan jasa, industry dan peribadatan. Diantara penggunaan lahan tersebut, pada segmen 20 didominasi oleh sawah dengan luas 72,15 ha dan merupakan kawasan budidaya.

Segmen 21 merupakan wilayah perkotaan dan berdasarkan hasil analisis transek memiliki bentukan sungai $\mathrm{V}$ bermeander, tidak bertanggul serta berada pada tingkat rawan bencana banjir C3 (rendah) dengan jenis penggunaan lahan di sempadan sungainya adalah perumahan, kebun campur, sawah, dan industri. Diantara penggunaan lahan tersebut, pada segmen 21 didominasi oleh sawah dengan luas 35,52 ha dan merupakan kawasan budidaya.

\section{Analisis Tipologi Sungai Wilayah Kajian Kecamatan Kapas}

Segmen 1 berada pada kali rengel, merupakan wilayah perkotaan dan berdasarkan hasil analisis transek memiliki bentukan sungai $\mathrm{V}$ bermeander, tidak bertanggul serta berada pada tingkat rawan bencana banjir C3 (rendah) dengan jenis penggunaan lahan di sempadan sungai nya adalah perumahan, kebun campur, sawah irigasi., pendidikan, perdagangan dan jasa, industri, peribadatan, tegalan dan perkantoran. Diantara penggunaan lahan tersebut, pada segmen 1 didominasi oleh kebun campur dengan luas 37,01 ha dan merupakan kawasan budidaya. Berikut merupakan peta segmen 1 .

Segmen 2 berada pada sungai kali rengel, merupakan wilayah perkotaan dan berdasarkan hasil analisis transek memiliki bentukan sungai $U$ tidak bermeander, tidak bertanggul serta berada pada tingkat rawan bencana banjir C3 (rendah) dengan jenis penggunaan lahan di sempadan sungai nya adalah perumahan, kebun campur, pendidikan. sawah irigasi dan tegalan. Diantara penggunaan lahan tersebut, pada segmen 2 didominasi oleh sawah irigasi dengan luas 28,28 ha dan merupakan kawasan budidaya. Berikut merupakan peta segmen 2 .

Segmen 3 berada pada sungai kali semanding, merupakan wilayah perkotaan, dan berdasarkan hasil analisis transek memiliki bentukan sungai $\mathrm{V}$ bermeander, tidak bertanggul serta berada pada tingkat rawan bencana banjir C3 (rendah) dengan jenis penggunaan lahan di sempadan sungai nya adalah perumahan, sawah irigasi, kebun campur, pendidikan, perdagangan dan jasa, industri, peribadatan perkantoran dan tegalan. Diantara penggunaan lahan tersebut, pada segmen 3 didominasi oleh sawah irigasi dengan luas 66,37 ha dan merupakan kawasan budidaya. Berikut merupakan peta segmen 3.

Segmen 4 merupakan wilayah perkotaan dan berdasarkan hasil analisis transek memiliki bentukan sungai $\mathrm{V}$ bermeander, tidak bertanggul serta berada pada tingkat rawan bencana banjir C3 (rendah) dengan jenis penggunaan lahan di sempadan sungainya adalah perumahan, sawah irigasi, kebun campur, perdagangan dan jasa, industri, peribadatan dan tegalan. Diantara penggunaan lahan tersebut pada segmen 4 , didominasi oleh kebun campur dengan luas 21,31 ha dan merupakan kawasan budidaya. Berikut merupakan peta segmen 4 Kecamatan Kapas.

Segmen 5 merupakan wilayah perkotaan dan berdasarkan hasil analisis transek memiliki bentukan sungai $\mathrm{U}$ bermeander, tidak bertanggul serta berada pada tingkat rawan bencana banjir C3 (rendah) dengan jenis penggunaan lahan di sempadan sungai nya adalah perumahan, kebun campur, sawah, pendidikan, perdagangan dan jasa, industri, peribadatan, tegalan, perkantoran, dan kesehatan. Diantara penggunaan lahan tersebut, pada segmen 5 didominasi oleh perumahan dengan luas $35,84 \mathrm{Ha}$ dan merupakan kawasan budidaya. Berikut merupakan peta segmen 5 Kecamatan Kapas.

Segmen 6 berada pada kali pacal, merupakan wilayah perkotaan dan berdasarkan hasil analisis transek memiliki bentukan sungai $U$ bermeander, bertanggul serta berada pada tingkat rawan bencana banjir C3 (rendah) dengan jenis penggunaan lahan di sempadan sungai nya adalah perumahan, kebun campur, sawah, pendidikan, perdagangan dan jasa, industri, peribadatan, tegalan, perkantoran, kesehatan serta pariwisata dan hiburan. Diantara penggunaan lahan tersebut, pada segmen 6 
didominasi oleh sawah irigasi dengan luas 71,67 Ha dan merupakan kawasan budidaya.

Segmen 7 berada pada kali pacal dan memiliki bentukan sungai $U$, tidak bermeander, tidak bertanggul dan berada pada tingkat rawan bencana banjir C3 (rendah) dengan jenis penggunaan lahan di sempadan sungai nya adalah permukiman, sawah irigasi, kebun campur, perdagangan dan jasa, kesehatan, peribadatan, pendidikan, perkantoran dan tegalan. Diantara penggunaan lahan tersebut, pada segmen 7 didominasi oleh sawah irigasi dengan luas 16,29 ha dan merupakan kawasan budidaya. Berikut merupakan peta segmen 7 Kecamatan Kapas.

Segmen 8 berada pada kali pacal, merupakan wilayah perdesaan dan berdasarkan hasil analisis transek memiliki bentukan sungai $\mathrm{V}$ bermeander, tidak bertanggul serta berada pada tingkat rawan bencana banjir C3 (rendah) dengan jenis penggunaan lahan di sempadan sungai nya adalah perumahan, sawah irigasi, kebun campur, perdagangan dan jasa, industri, peribadatan, pendidikan dan perkantoran. Diantara penggunaan lahan tersebut pada segmen 8 didominasi oleh sawah irigasi yaitu sebesar 38,55 Ha dan merupakan kawasan budidaya. Berikut merupakan peta segmen 8 Kecamatan Kapas.

Segmen 9 merupakan wilayah perdesaan dan berdasarkan hasil analisis transek memiliki bentukan sungai $\mathrm{V}$ bermeander, tidak bertanggul serta berada pada tingkat rawan bencana banjir C3 (rendah) dengan jenis penggunaan lahan di sempadan sungai nya adalah permukiman, sawah irigasi, kebun campur, perdagangan dan jasa, industry, pariwisata dan hiburan, pendidikan, perkantoran dan tegalan. Diantara penggunaan lahan tersebut pada segmen 8 didominasi oleh sawah irigasi yaitu sebesar 16,12 ha dan merupakan kawasan budidaya. Berikut merupakan segmen 9 Kecamatan Kapas.

Segmen 10 merupakan wilayah perdesaan dan berdasarkan hasil analisis transek memiliki bentukan sungai $U$ bermeander, tidak bertanggul serta berada pada tingkat rawan bencana banjir C3 (rendah) dengan jenis penggunaan lahan di sempadan sungai nya adalah permukiman, sawah irigasi dan perkebunan. Diantara penggunaan lahan tersebut pada segmen 10 didominasi oleh permukiman dengan luas 92,91 $\mathrm{Ha}$ dan merupakan kawasan budidaya. Berikut merupakan peta segmen 10 Kecamatan Kapas.

Segmen 11 berada pada kali kedungbanteng, merupakan wilayah perdesaan dan berdasarkan hasil analisis transek memiliki bentukan sungai $U$, bermeander, bertanggul serta berada pada tingkat rawan bencana banjir C3 (rendah) dengan jenis penggunaan lahan di sempadan sungai nya adalah permukiman, sawah irigasi, perkebunan dan industry. Diantara penggunaan lahan tersebut pada segmen 11 didominasi oleh permukiman dengan luas sebesar 26,35 ha dan merupakan kawasan budidaya.

Segmen 12 berada pada kali kedungbanteng, merupakan wilayah perdesaan dan berdasarkan hasil analisis transek memiliki bentukan sungai $U$ tidak bermeander, tidak bertanggul serta berada pada tingkat rawan bencana banjir C3 (rendah) dengan jenis penggunaan lahan di sempadan sungai nya adalah permukiman dan sawah irigasi. Diantara penggunaan lahan tersebut pada segmen 12 didominasi oleh permukiman dengan luas 78,27 ha dan merupakan kawasan budidaya.

Segmen 13 berada pada kali rengel, merupakan wilayah perdesaan dan berdasarkan hasil analisis transek memiliki bentukan sungai $U$ bermeander, tidak bertanggul serta berada pada tingkat rawan bencana banjir C3 (rendah) dengan jenis penggunaan lahan di sempadan sungai nya adalah permukiman, sawah irigasi dan tanah kosong. Diantara penggunaan lahan tersebut pada segmen 13 didominasi oleh sawah irigasi dengan luas sebesar 39,36 dan merupakan kawasan budidaya.

Segmen 14 berada pada kali rengel, merupakan wilayah perdesaan dan berdasarkan hasil analisis transek memiliki bentukan sungai $\mathrm{U}$ bermeander, tidak bertanggul serta berada pada tingkat rawan bencana banjir C3 (rendah) dengan jenis penggunaan lahan di sempadan sungai nya adalah permukiman dan sawah irigasi. 
Diantara penggunaan lahan tersebut pada segmen 14 didominasi oleh permukiman dengan luas sebesar 77,48 ha dan merupakan kawasan budidaya.

Segmen 15 berada pada kali rengel dan kali ralongdowo, merupakan wilayah perdesaan serta berdasarkan hasil analisis transek memiliki bentukan sungai $\mathrm{V}$ bermeander, tidak bertanggul dan berada pada tingkat rawan bencana banjir C3 (rendah) dengan jenis penggunaan lahan di sempadan sungai nya adalah permukiman, sawah irigasi dan sawah tadah hujan. Diantara penggunaan lahan tersebut pada segmen 15 didominasi oleh jenis sawah yaitu sawah irigasi dan sawah tadah hujan yaitu kawasan budidaya.

Segmen 16 berada pada kali kedungbanteng, merupakan wilayah perdesaan dan berdasarkan hasil analisis transek memiliki bentukan sungai $\mathrm{V}$ bermeander, tidak bertanggul serta berada pada tingkat rawan bencana banjir C3 (rendah) dengan jenis penggunaan lahan di sempadan sungai nya adalah permukiman, sawah irigasi dan perkebunan. Diantara penggunaan lahan tersebut pada segmen 16 didominasi oleh permukiman dengan luas sebesar 57,11 ha dan merupakan kawasan budidaya.

Segmen 17 berada pada kali kedungbanteng, merupakan wilayah perdesaan dan berdasarkan hasil analisis transek memiliki bentukan sungai $\mathrm{V}$ bermeander, tidak bertanggul serta berada pada tingkat rawan bencana banjir C3 (rendah) dengan jenis penggunaan lahan di sempadan sungai nya adalah permukiman dan sawah irigasi. Diantara penggunaan lahan tersebut pada segmen 17 didominasi oleh sawah irigasi dengan luas sebesar 127,24 ha dan merupakan kawasan budidaya.

Segmen 18 berada pada Kali Ralongdowo, merupakan wilayah perdesaan dan berdasarkan hasil analisis transek memiliki bentukan sungai $\mathrm{V}$ bermeander, tidak bertanggul dan berada pada tingkat rawan bencana banjir C3 (rendah) dengan jenis penggunaan lahan di sempadan sungainya hanya terdapat sawah irigasi dengan luas sebesar 99,78 ha dan merupakan kawasan budidaya.

Segmen 19 berada pada Kali Ralongdowo, merupakan wilayah perdesaan dan berdasarkan hasil analisis transek memiliki bentukan sungai $\mathrm{V}$ bermeander, tidak bertanggul dan berada pada tingkat rawan bencana banjir C3 (rendah) dengan jenis penggunaan lahan di sempadan sungainya hanya terdapat sawah irigasi dengan luas sebesar 80,72 ha dan merupakan kawasan budidaya.

\section{Arahan Penataan Ruang Kawasan Sempadan Sungai di Wilayah kajian Kecamatan Bojonegoro}

Analisis dan pembahasan yang telah dihasilkan dan dilakukan yakni identifikasi bentukan sungai, analisis tipologi karakteristik di sekitar sungai hingga ke penentuan garis sempadan sungainya, didapatkan kesimpulan berupa rekomendasi arahan pemanfaatan ruang yang perlu dilakukan di daerah sempadan sungai. Oleh karena itu arahannya dapat dilihat pada tabel arahan penataan ruang berikut ini:

Tabel 2. Arahan Penataan Ruang Kawasan Sempadan Sungai

\begin{tabular}{llll}
\hline \multicolumn{1}{c}{ Tingkat } & \multicolumn{3}{c}{ Perijinan } \\
\cline { 2 - 4 } Risiko Banjir & Ijin Terbatas & Ijin Bersyarat & Dilarang \\
\hline C2 (Risiko & $\begin{array}{l}\text { Kawasan } \\
\text { Lindung dan } \\
\text { sedang) }\end{array}$ & $\begin{array}{l}\text { sebagian } \\
\text { budidaya }\end{array}$ & - \\
\hline
\end{tabular}




\begin{tabular}{|c|c|c|c|}
\hline \multirow{2}{*}{$\begin{array}{c}\text { Tingkat } \\
\text { Risiko Banjir }\end{array}$} & \multicolumn{3}{|c|}{ Perijinan } \\
\hline & Ijin Terbatas & Ijin Bersyarat & Dilarang \\
\hline $\begin{array}{l}\text { C3 (Risiko } \\
\text { rendah) }\end{array}$ & $\begin{array}{l}\text { Kawasan } \\
\text { Lindung dan } \\
\text { sebagian } \\
\text { budidaya }\end{array}$ & $\begin{array}{l}\text { Permukiman, } \\
\text { perdagangan, } \\
\text { industri, } \\
\text { pertanian, } \\
\text { pertambangan, } \\
\text { pariwisata, } \\
\text { perhubungan }\end{array}$ & $\begin{array}{l}\text { Kegiatan yang } \\
\text { menyebabkan } \\
\text { terjadinya } \\
\text { banjir }\end{array}$ \\
\hline
\end{tabular}

\section{KESIMPULAN}

Kecamatan Bojonegoro merupakan kecamatan yang rawan banjir dengan didominasi KRB Banjir sedang sehingga setiap kegiatan-kegiatan budidaya memiliki ijin bersyarat sedangkan pada Kecamatan Kapas merupakan kecamatan yang tidak berpotensi banjir karena seluruh segmen sungai nya berada pada KRB Banjir rendah sehingga semua kegiatan-kegiatan budidaya di Kecamatan Kapas di ijinkan.

Setelah dilakukannya penentuan sempadan sungai di Wilayah kajian Kecamatan Bojonegoro dan identifikasi kepemilikan lahan pada daerah sempadan sungai, terdapat 17 (tujuh) segmen pada Kecamatan Bojonegoro yang daerah sempadan sungainya memiliki status kepemilikan lahan perorangan sehingga perlu dilakukannya perhitungan perkitaan biaya ganti rugi lahan.

\section{REFERENSI}

Ariyani, Nita. 2020. Pengaturan Ideal tentang Pengelolaan Daerah Aliran Sungai di Indonesia (Studi di Sungai Serang Kabupaten Kulon Progo). Jurnal Hukum IUS QUIA IUSTUM NO. 3 VOL. 27 SEPTEMBER 2020: 592 - 614

Blodget, David. 2021. Mainstems: A logical data model implementing mainstem and drainage basin feature types based on WaterML2 Part 3: HY Features concepts. Environmental Modelling and Software 135 (2021) 104927.

Čerkasova, Natalja. 2016 Curonian Lagoon drainage basin modelling and assessment of climate change impact.
Oceanologia Volume 58, Issue 2, AprilJune 2016, Pages 90-102 Elsavier.

Fatahilah, Muhammad. 2013. "Kajian Keterpaduan Pengelolaan Daerah Aliran Sungai (Das) Garang Provinsi Jawa Tengah", Jurnal Geografi, Volume 10 No. 2, Juli 2013, hlm. 137.

Gay dkk. 2018. Perencanaan Kawasan Sempadan Sungai Sawangan Di Kota Manado. Jurnal Spasial. No. 1 Vol. 5 2015.

Mostert, Erik. 2017. River Basin Management and Community: The Great Ouse Basin, 1850-Present. International Journal of River Basin Management. DOI: 10.1080/15715124.2017.1339355.

ISSN: 1571-5124 E-ISSN: 1814-2060

Putra, Deki Andes. 2019. Pengelolaan Sumberdaya Alam Berbasis Masyarakat Dalam Upaya Konservasi Daerah Aliran Sungai Lubuk Langkap Desa Suka Maju Kecamatan Air Nipis Kabupaten Bengkulu Selatan. NATURALIS Jurnal Penelitian Pengelolaan Sumberdaya Alam dan Lingkungan. Volume 8 Nomor 1, April 2019. PISSN: 2302- 6715 E-ISSN: 2654- 7732.

Sari, Widya. 2014. Identifikasi Pemanfaatan Lahan Sempadan Sungai Sumbergunung di Kota Batu. Jurnal Sumberdaya Alam dan Lingkungan. No. 2 Vol. 1, 2014

Suprapti dkk, 2014. Strategi Pengendalian dan Pengawasan Sempadan Sungai. (STudi Kasus: Kali Surabaya di Kecamatan Driyorejo dan Wringinanom Kabupaten Gresik). Jurnal Sosial Humaniora. No. 2 Vol. 7, November 2014.

Widiyanto, Ary. 2018. Pola Penggunaan Lahan di Sepadan Sungai Cinangka, Sub Daerah Aliran Sungai Cimanuk Hulu. Jurnal Penelitian Pengelolaan 
Daerah Aliran Sungai. No. 1 Vol. 2 Maret 2018: 61-72. 